\title{
Erkek infertilitesinde spermatozoon DNA hasarının rolü ve önemi
}

\author{
Burcu YALÇIN ${ }^{1}$, Mesut ÇEVİK ${ }^{1}$
}

${ }^{1}$ Ondokuz Mavıs Üniversitesi, Dölerme ve Suni Tohumlama Anabilim Dalı, Samsun/TÜRKIYY

Anahtar Kelimeler:
DNA hasar1
infertilite
spermatozoon

Key Words:

DNA damage

infertility

spermatozoon

Gelis Tarihi: 25.09.2018

Kabul Tarihi: 03.12.2018

Yayin Tarihi: 31.12.2018

Makale Kodu:463669

Sorumlu Yazar:

M. CCEVIK

(cevikm@omu.edu.tr)

ORCİD:

B. YALÇIN: 0000-0002-5728-1478

M. CEVIIK: 0000-0002-0754-6116

\begin{abstract}
ÖZ
Erkeğe bağlı infertilite, genetik ve epigenetik nedenlerden kaynaklanan karmaşık etiyoloji, döl veriminin normal sınırlar altında bulunmasına sebep olan bir hastalıktır. İnfertilite ile spermatozoonun genetik yapısı arasında kuvvetli bir birliktelik bulunmaktadır. Çeşitli iç ve dış kaynaklı sebeplerden dolayı spermatozoonun Deoksiribo nükleik asit (DNA) yapisında farklı düzeylerde hasarlar meydana gelmektedir. İnfertil erkeklerde spermatozoon DNA hasarı yüksek olarak saptanmaktadır. Çeşitli DNA hasar tamir mekanizmaları DNA'da meydana gelen hasarın tipine uygun olarak devreye girmekte ve hasar tamirinin gerçekleştirilmesi sonucu genomik kararlılık korunmakta ve hücre yaşamını sürdürebilmektedir. Hasar nedenlerinin çoğalması, onarım mekanizmalarındaki aksaklıklar gibi nedenlerle hücre ölümü, fertilizasyon kapasitesinde azalma, spermatozoon genom bütünlüğ̈̈nde bozulma, infertilite ve mutasyonlar meydana gelebilmektedir. Spermatozoon DNA'sında şekillenen bu hasarların tespiti amacıyla tek hücre jel elektroforezi, tunel, spermatozoon kromatin yapısı analizi gibi birçok metot kullanılmaktadır. Mevcut veriler 1şı̆̆ında, daha iyi kalitede spermatozoonlara sahip olan hayvanların seçiminde, reprodüktif biyoteknolojiler ve yardımcı üreme tekniklerinde spermatozoon seçimi önemli olsa da, erkek infertilitesi tanı ve tedavisinde spermatozoon DNA hasarı olup olmadığının değerlendirilmesi ayrı bir önem arz etmektedir.
\end{abstract}

\section{The role and importance of spermatozoon dna damage in male infertility}

\begin{abstract}
Infertility is a disease with complex etiology resulting from genetic and epigenetic causes, which causes the fertility to be under normal limits in males. There is a strong association between the infertility and the genetic structure of the spermatozoon. Due to various internal and external causes, different levels of damage can be occur in to the spermatozoon (Deoksiribo nucleic acid) DNA structure. Infertile men have high spermatozoon DNA damage.. Various DNA damage repair mechanisms are join in accordance with the type of damage that occurs in DNA and the completion of damage repair preserves the resulting genomic stability and can lead to cell survival. The causes of cell death, reduction in fertilization capacity, deterioration in the integrity of the spermatozoon genome, infertility and mutations can occur due to the proliferation of damage causes and deficiencies in repair mechanisms. Many methods such as the single cell gel electrophoresis, tunel, spermatozoon chromatin structure assay are used to measure spermatozoon DNA damage. In the light of existing data, although selecting quality of spermatozoa are important in reproductive biotechnology and assisted reproductive techniques, evaluating spermatozoon DNA damage is special importance in diagnosis and treatment of male infertility.
\end{abstract}

\section{GİRIŞ}

Erkeğe birçok in vivo ve in vitro çalş̧mada gösterilmiştir. Spermatozoon Deoksiribo nükleik asit (DNA) hasarnna bağlı olarak gelişen infertilite, genetik ve epigenetik nedenlerden kaynaklanan karmaşık etiyolojili bir hastalıktır. Spermatozoonun genetik yapısındaki bozulma ile infertilite arasındaki ilişki, fertilizasyon şansının tahmin edilmesinde ve oluşan embriyonun maruz kalabileceği muhtemel risklerin belirlenmesinde önem kazanmaktadır $(1,2)$.

Günümüzde insanlar ve birçok hayvan türü için spermanın manipülasyonları, in vitro fertilizasyon, klonlama ve transgenezis gibi reprodüktif biyoteknolojilerin etkin şekilde kullant$\mathrm{m} ı$ büyük önem kazanmıştır. Dolayısıyla, sperma kalitesinin ve fertilizasyon yeteneğinin tam olarak değerlendirilmesinde spermatozoon DNA bütünlügünü değerlendiren testler daha çok ön plana çıkarılması yönünde bir eğilim oluşmuştur. Spermatozoon DNA bütünlüğ̈üü değerlendiren testler özellikle daha iyi kalitede spermatozoonlara sahip olan hayvanların seçiminde önemli bir role sahip olup, aynı zamanda yardımcı üreme tekniklerinin uygulandığ durumlarda spermatozoon seçiminde başvurulması gereken testlerdir $(1,2,3)$.

$\mathrm{Bu}$ derlemenin amac1; spermatozoonun fertilite potansiyelinin temel belirleyicisi olan DNA yapisını güncel verilerin 1şığında incelemek, spermatozoon DNA'sında oluşan hasarların fertilite açısından önemini ve bu hasarı oluşturan faktörleri ortaya koymak olmuştur. Ayrıca, bu hasarların erkek damızlık- 
ların fertilite potansiyeli üzerindeki etkilerinin değerlendirmesi konusunda tespit ve önerilerde bulunulmuştur.

\section{Spermatozoon ve DNA Yapisi}

Erkek üreme hücresi ilk kez Johan Hamm ve Leeuwenhook (1677) tarafindan gözlenmiş ve mikroskobik görünümü tarif edilmiştir. Ancak, bu araştırmacılar spermatozoonların fertilizasyondaki rolünü yanlış anlamışlardır. Onlara göre spermatozoonlar minyatür insan şekillerini taşımakta ve bunlar dişi üreme kanalında büyüyüp gelişmekteydi. Erkek üreme hücresi başlangıçta bir hayvancığa benzetilmiş ve Karl Ernst V. Baer (1827) tarafindan "spermatozoon" adı verilmiştir (4). Spermatozoon DNA's1, benzersiz bir biçimde kompakt haldedir ve somatik hücrelerinkinden büyük ölçüde farklı olarak organize edilmektedir. Bu DNA organizasyonu, çok sıkı sarılmış genetik bilginin oosite aktarılmasını sağlamakla kalmayıp, aynı zamanda DNA'nın gelişmekte olan genetik bilgiye erişebilmesi için embriyolara uygun fiziksel ve kimyasal bir biçimde verilmesini sağlamaktadır (5). Ward (1997) yapmış olduğu çalışmaları ve diğer araştırma temellerini baz alarak spermatozoon DNA paketlemesi için Şekil 1'de de gösterilmiş olan bir model sunmuştur. Bu modelde, olgun spermatozoonun DNA paketlenmesinde; (I) Nükleer halka tarafindan kromozomal bağlanma, (II) spermatozoon DNA halka alanı organizasyonu, (III) protamin dekondensasyonu ve (IV) kromozom organizasyonu olmak üzere dört aşama belirtilmektedir. Sunulan bu modelde, spermatozoon çekirdeğinin organizasyonunun karmaşıklı̆̆1na vurgu yapilmakla birlikte, DNA'daki anormalliklerin genel olarak nükleer organizasyonda bozulmalara sebep olabileceği varsayımı da desteklenmektedir (6). Spermatozoon nükleusunda paternal genom fonksiyonel olarak durağan kalmakta ve DNA'sinı protaminlerle paketledikten sonra bu durumunu korumaktadir (7). Bu durum, spermatozoonun nükleer hacminde dikkat çekici bir azalma ile fark edilen morfolojik değişimle belirgin hale gelmektedir. Oluşan bu değişikliklere rağmen, hem insan hem de hayvan spermatozoonu genomu boyunca tesadüfi olmayan bölgelerinde düşük seviyede nükleozomlarla (histonlar) paketlenmiş olarak kalır (8).

\section{Spermatozoonun Genetik Yapısındaki Hasarlar ve Önemi}

1990’lı yıllardan beri DNA hasarlarının kökeni olarak düşünülen kromatin paketlenmesi ile ilişkili 3 yaklaşım öne sürülmüştür. Bunlardan birincisi, DNA hasarı ve zayıf kromatin paketlenmesi arasında nedensel bir ilişki bulunmasıdır. Bu yaklaşımda, spermiyogenezis sırasında ortaya çıkan hatalar sebebiyle, zayıf sıkıştırılmıs spermatozoon kromatin paketlenmesine yol açarak, spermiasyon ve ejakülasyon arasındaki bir noktada DNA parçalanmasına duyarlılık durumu oluşmaktadır. İkincisi, DNA hasarı ve zayıf kromatin paketlenmesi arasındaki bağımsız bir ilişkidir. Bu yaklaşımda, spermatozoon hücrelerine özgü epigenetik düzenlenmenin (protaminasyonun) ve DNA parçalanmasının, spermiyogenezisin altında yatan kalitesini yansıtan bağımsız fenomen olduğunu kabul eder. Buna göre; DNA paketlenmesi ile ilişkili olarak torsiyonal stresi gidermek için spermatidlerde fizyolojik olarak DNA kırıkları oluşur, gama H2AX (gamma- H2AX; H2A histonu ailesi, $\mathrm{X}$ üyesi) tarafindan histon fosforilasyonu ile işaretlenir ve spermatozoa germinal epitelyumdan salınmadan önce topoizomeraz tarafindan tamamen kararlı hale getirilir (9). Üçüncüsü ise DNA hasarı ve kromatin paketlenmesi arasındaki ilişki bir artefakttır. Bu yaklaşımda, ilk çalışmalardaki DNA hasarı tespitlerinde kullanılan yöntemlerde bir DNA sekansinın hedef nükleotidlerini etiketlenmiş analoglarıyla değiştirmek için enzimlerin kullanımına bağlı olması gerçeğine dayanmaktadır.

Bu üç yaklaşımdan hangisinin doğru olduğunu aydınlatmak için germ hattında DNA hasarının indüklendiği mekanizmaların incelenmesi gerekmektedir (9). Ejakülattaki spermatozoon DNA hasarından sorumlu faktörler halen tam olarak açıklı̆ga kavuşamamıştır. Spermatozoonda oluşan DNA hasarına insan ve fare, at, domuz, balık gibi pek çok hayvan türünde rastlanmaktadır (10). DNA'da oluşan bu hasarların başlıcaları; kromatin yapısının bozulması, DNA bazlanının oksidasyonu, yanlış

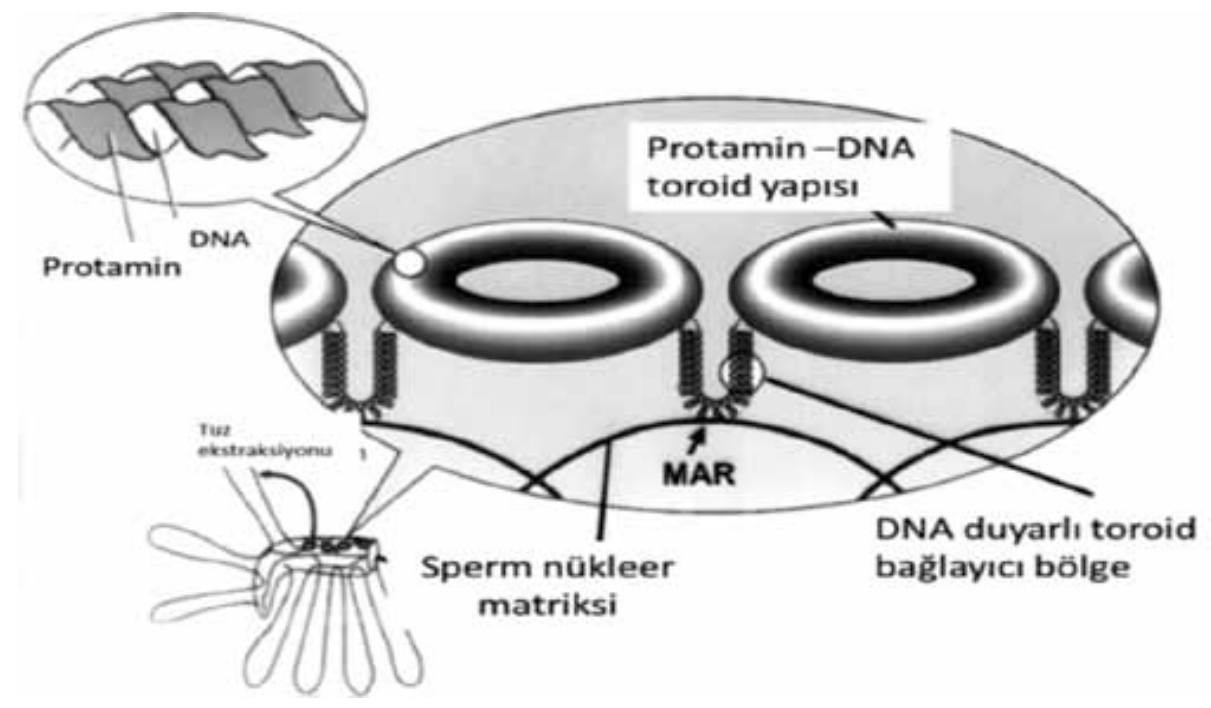

Şekil 1 Spermatozoon DNA paketlenmesi.

Figure 1 DNA damaging of sperm. 
eşleşme ve tubulin polimerizasyonun baskılanması, bazların kimyasal olarak değişmesi, kromatin yapısındaki anomaliler, DNA zincirinin kırılması, DNA-DNA ve DNA-protein çaprazlaşmaları, DNA da mutasyonlar gibi bir takım yapısal bozulmalardır. DNA hasarıyla karşılaşan bir hücre için üç seçenek vardir. Birincisi, apoptotik yolu aktive etmektir. Bu aktivasyon hücreleri yok edecek ve canlılı̆g zayıflatarak hücre ölümüne yol açacak olan bir süreçtir. İkinci seçenek, oluşan hasarı tolere etmeye çalışmak olup, bu seçenek yeni nesillerde mutasyona neden olabilmektedir. Üçüncü ve en iyi seçenek ise hasar1 onarmaktır. Bu onarım sistemleri, organizmaları korur ve genomik bütünlüğün korunması için kısa sürede hasarı neredeyse tamamen onarır. Zaten onarilamayacak durumda ise hücrenin direkt olarak apoptozis ile ölüme gitmesi kaçınılmazdır $(11,12)$.

\section{Spermatozoon DNA Hasar Sebepleri}

Spermatozoon kromatin/DNA yapısında meydana gelebilecek hasarların aşağıda belirtilen potansiyel sebeplerden kaynaklandiğ1 düşünülmektedir.

\section{İç Kaynaklı Sebepler}

Olgun spermatozoonun sıkıştırılmış kromatininde DNADNA veya DNA-protein krossing over oluşması somatik hücrelere göre daha fazla şekillenmektedir. DNA hasarlı spermatozoa popülasyonlarında çapraz bağlanmış kromatine sıklıkla rastlanılmaktadır ve moleküler ölçüde temeli halen daha tam olarak bilinmemektedir (13). Kromatin paketlenmesi, histonların hiper-asetilasyonuyla kromatini gevşetmek ve topoizomeraz tarafindan kırılmalarını başlatmak için endojen nükleaz aktivitesine ihtiyaç duyan bir adımı içermektedir. Epididimal taşınma sırasında yeni protamin çekirdeği etrafindaki kromatin paketlenmesi tamamlanarak DNA bütünlüğü eski haline getirilmektedir. Bununla birlikte, geçici kırılmalar onarılamazsa, ejakülattaki spermatozoonlarda DNA kırılma hasarları oluşabilmektedir $(13,14)$. Spermatozoon protamin ekspresyonundaki değişiklikler erkek infertilitesiyle doğrudan ilişkilidir. Geç spermiyogenezis sırasında çok aşamalı bir süreçle \% 85-95 oranında histonların yerini protaminler almaktadır. Histonlar hiperasetilasyon altında olup, öncelikle testislere özgü histonlarla ve ardindan da geçiş proteinleriyle yer değiştirmektedir. Daha sonrasinda geçiş proteinleri Protamin 1 (P1) ve 2 (P2) ile değiştirilir. P1 ve P2 normal olarak spermatozoonlarda 1: 1 oranında ifade edilmektedir ve spermatozoon DNA'sinın sik1 bir şekilde paketlenmesini sağlarlar (15). Anormal derecede yüksek veya düşük P1/P2 oranları ile spermatozoon DNA hasarlarında artış, fertilizasyon oranlarında, embriyo kalitesinde bozulmalar ve düşük gebelik oranları arasında kesin olarak ilişki bulunduğu bildirilmektedir (16). Erkek germ hücreleri transkripsiyonel ve translasyonel olarak sessiz olduklarından dolay1, bu hücreler yüksek oranda farklılaşmış spermatidlere dönüşürlerken, apoptozis ile programlanmış hücre ölümüne maruz kalmaları giderek azalmaktadır. Hücre ölümüne sebep olarak apoptotik cevap oluşturarak farklılaşan haploid germ hücreleri çekirdek içinde DNA hasarına neden olan süreci kısıtladıklarında, fertilizasyon yeteneğini kaybetmemiş olgun spermatozoonlar oluşabilmektedir (17).

Reaktif oksijen türlerinin (ROS) fizyolojik düzeyleri somatik hücrelerde olduğu gibi spermatozoon fonksiyonlarının düzenlenmesinde de önemli rol oynamaktadır. ROS türleri oldukça reaktiftir ve DNA molekülü de dahil olmak üzere herhangi bir hücre yapısına direkt olarak zarar verebilir. Spermatozoonların karışık biyokimyasal yapısında ROS’lar sinyal dönüştürücüler olarak önemli görevler üstlenmektedir. Olgunlaşma, hiperaktivasyon, kapasitasyon, akrozom reaksiyonu ve spermatozoon-oosit füzyonu gibi olaylarda ROS'un katkı sağladığ1 bilinmektedir (18). Spermatozoon fonksiyonları üzerinde önemli görevlere sahip olan ROS, organizmada antioksidan savunma sistemlerini aşan düzeylere ulaştı̆̆ında patolojik etki göstermektedir. Spermatozoon DNA'nın sikıca paketlenmesi ve seminal plazmada antioksidanların bulunması, spermatozoon DNA'sının ROS saldırılarına karşı korunduğu teorisine rağmen yine de oksidatif stresin DNA hasarlarına neden olduğu ve bu hasarların da erkek infertilitesinde önemli bir yer tuttuğu bildirilmektedir $(18,19)$. Ayrıca son yıllarda yapılan araştırmalarda, yüksek ROS seviyeleri üreten olgunlaşmamış spermatozoonların, olgun spermatozoonlarda DNA hasarında artışa neden olduğunu önemle vurgulanmaktadır. Bu hasar, seminifer tübüllerden epididimise spermiasyon sonrasında ve ejakülasyon sonrasında ortaya çıkmaktadır. ROS spermatozoon DNA'sına doğrudan veya dolaylı olarak kaspaz veya endonükleaz aktivasyonlar1 yoluyla zarar verebilir. Olgunlaşmamış spermatozoonların, olgun spermatozoonlar ile birlikte santrifüj edilmesi olgun spermatozoonlarda DNA hasarına neden olabilir, çünkü bu koşullar altında olgun ve olgunlaşmamış spermatozoonlar yakin temas halindedir (19).

\section{Dış Kaynaklı Sebepler}

Sperma alma yöntemleri (suni vajen, elektrojakülasyon vb.), sperma alma mevsimi (mevsimsel kızginlık gösteren hayvanlarda sezon içi ya da dişı durumu), sulandırıcılar ve ön işlem prosedürleri (y1kama protokolleri) spermatozoon DNA kalitesi üzerinde önemli etkilere sahiptir. Yetiştirme mevsiminde alınan ve uygun sulandirıcılarla sulandırılan sperma örneklerinde ve sperma alma yöntemi olarak suni vajen ile toplanan ejakülatlarda daha iyi spermatozoon kalitesi gözlendiği bildirilmektedir (20). Ancak, türler arasında ve hatta aynı türün bireyleri arasında da çeşitli farklılıklar bulunmaktadır. Tüm türlerde, ejakülasyon sonrası spermada bakteri üremesi nedeniyle spermatozoon DNA hasarında belirgin bir artış oluşmakta ve bu nedenle uygulanan antibiyotik ilavesi ile enfeksiyona bağlı olarak oluşan DNA hasar düzeyleri de azaltılabilmektedir (21). In vitro fertilizasyon uygulamalarının spermatozoon DNA'sına zarar vermediği gibi histon içeriğini de etkilemediği bildirilmiştir. Ayrıca in vitro embriyo üretimi amaçlı spermada daha yüksek motilite oranı sağladığ1 ve DNA hasarını azalttığı için Percoll ve Swim-up separasyon tekniklerinin kombinasyonu önerilmektedir $(2,22)$. Yapılan çalışmalar, geyik ve domuz gibi türlerde cinsiyet tayini yapılmasinın spermatozoonların DNA kalitesini etkilemediğini göstermiştir. Ancak, boğa spermas1 üzerine çalışmalar halen devam etmektedir (23). Spermatozoon DNA'sına kriyoprezervasyon ve depolama sıcaklığının etkisi birçok türde incelenmiş ve soğutma aşamasında uygulanan $5-15^{\circ} \mathrm{C}$ arasındaki sicaklıkların, $20-37^{\circ} \mathrm{C}$ aralığındaki gibi daha yüksek sicakliklara oranla spermatozoon DNA'sını uzun süre koruduğu bildirilmektedir. Ortam sıcaklığ1 arttıkça ayg1r, tavşan, köpek ve boğa spermatozoonlarında DNA hasarının arttığı bildirilmektedir (24). Spermanın kriyoprezervasyon aşamasindan önce ve sonra spermatozoon DNA hasar1 üzerine 
yapılan farklı çalışmalarda, kriyoprezervasyonun DNA hasar1na sebep olduğu belirlendiği için dikkatle ele alınması gereken bir konudur. Şimdiye kadar analiz edilen tüm memeli türlerinde gözlemlenen, spermatozoon DNA kalitesinin diferansiyel ve türe özgü dinamik kaybının, reprodüktif sonuçlar üzerine negatif etkiye sebep olabileceği unutulmamalıdır (25). Bazı aşılar negatif olarak spermanin DNA kalitesini etkileyebilmektedir. Subkutan olarak uygulanan Miloxan'n (Clostridium perfringens tip C, D ve C. oedematiens tip B) koç spermasında DNA hasarlı spermatozoon yüzdesini 10 kat artırdığı kanıtlanmıştır. Bu nedenle aşılamadan en az bir ay sonrasina kadar sperma örneklerinin toplanmasından kaçınılmalıdır. Ancak, bu negatif etki geri dönüşümlü olabilmektedir (26).

\section{DNA Hasarının Tamir Mekanizmaları}

Memeli germ hücrelerinde bilinen ana tamir mekanizmalari; (a) nükleotid eksizyon tamiri, (b) baz eksizyon tamiri, (c) uyuşmazlık onarımı, (d) replikasyon sonrası tamir ve DNA çift zincir kopma onarımı'dır. Son y1llarda DNA sarmal kırıklarının tamir mekanizması ve biyolojik önemi ile ilgili önemli yeni bilgiler elde edilmiş ve DNA sarmal kırıklarının oldukça toksik bir DNA lezyonu olduğu tanımlanmıştır. Çünkü kromozom parçalanmasına, kromozom etki kaybına, translokasyonlara veya farklı genom düzenlenmelerine neden olabilirler (11). DNA hasar tamiri için çeşitli yollar gelişmiştir. Memeli hücrelerindeki en önemli DNA hasar tamir mekanizmaları, homolog olmayan uçların birleştirilmesi ve homolog rekombinasyonudur. Homolog rekombinasyonu hasarsız bir tamir şablonu kullanarak doğru DNA hasarı onarımı sağlarken, homolog olmayan uçların birleştirilmesi ile doğru bir onarım sağlanamaz. Her iki yol da memelilerde aktif olsa da, iki onarım yolunun genom stabilizasyonuna göreceli olan katkısı farklı hücre tiplerinde değişiklik göstermektedir.

Tamir mekanizmalarının biyolojik önemi üzerinde duruldugunda tamir mekanizması spermatogenezis sirasinda ve döllenmiş oosit ile erken embriyonik gelişim sırasında olmak üzere 2'ye ayırıp incelenebilir (21).

\section{Spermatogenezis Sirasındaki Tamir Mekanizması}

Bilindiği üzere spermatogenezis üç farklı aşamadan oluşur. Birincisi, spermatogoniaların mitotik bir seri bölünmeler sonucu primer spermatositlerin oluştuğu spermatositogenezis evresidir. İkinci aşama, primer spermatositlerin mayotik bölünmeler ile haploid spermatidlere dönüştüğü aşamadır. Spermiyogenezis olarak adlandırılan üçüncü aşama ise spermatidlerin olgun spermatozoonlara dönüşüm evresidir. Bu nedenle, germ hücrelerinin olgunlaşması haploid gamet üretmek için kromatinin yeniden modellenmesi gerektiren olağanüstü genomik bir yapılanmayı gerektirir (27). Bu işlem sırasında histonlar DNA'dan ç1karılır ve önce TP1 ve TP2 geçiş proteinleri ve ardından P1 ve P2 protaminleri ile yer değiştirirler. Olgun bir spermatozoonda, spermatozoon genomunun sadece küçük fakat iyi tanımlanmış fraksiyonu histon ile ilişkide kalır. Spermatozoonda anormal şekilde yüksek histon miktarı varlığı, o hücrelerin fertilizasyon potansiyelinin azalması ve fertilizasyon sonrası embriyonik ölüm riskinin artması ile ilişkilendirilebilir (28). Dolayisiyla, spermatozoonlarda histon tutulumu ve protamin eksikliği idiyopatik infertilitenin sebeplerinden kaynaklı olabilir, ancak bu sebeplerin altında yatan genetik ve mekanik nedenler halen belirsizdir. Spermiyogenezis sirasında histondan protamin bazlı kromatin'e geçiş aşamasında DNA zincirinde kırılmalar geçici fizyolojik bir durumla ilişkilendirilir. Bu DNA zincirindeki geçici kırılmalar spermiyogenezis boyunca tüm spermatidlerde devam eder ki bu kırılmalar spermiyogeneziste nükleoproteinlerin değişimi sırasında DNA'nın gevşemesiyle ilişkilidir (29).

\section{Oosit ve Embriyonik Gelişim Aşamasındaki Tamir Mekanizması}

DNA hasarlı spermatozoon, içinde bulunduğu hasarlı duruma rağmen fertilizasyon ve gelişim potansiyeline sahip olabilir. Spermatozoon DNA parçalanma seviyesine bağlı olarak üç durum beklenebilir: bazı durumlarda oosit tamir mekanizmalar1, DNA hasarını onarmak için yeterli olmayabilir ve embriyonun uterus içerisinde gelişmesi ve implantasyonu başarısızlıkla sonuçlanabilir ve sonraki aşamada abort oluşturabilir. Oluşan hasarın gametogenik DNA onarımından kurtulması veya spermatozoon hücrelerinde ekzojen faktörlerden zarar gelmesi durumunda hasar fertilizasyon boyunca başarıyla onarılabilir (30). Henüz fertilize olmuş bir embriyoda DNA hasarının tamiri, yumurtlamadan önce oositte biriktirilen ve depolanan maternal mRNA'lar ve proteinler sayesindedir. DNA tamir genleri, memeli gelişiminin ilk evrelerinde etki etmektedir. Oosit yeterince donanımlı değilse veya zigot tamir geninin etkisi doğru zamanda başlamazsa, embriyoların ölüme gideceği kesin bir durumdur. Genomun bütünlüğü, embriyonik gelişim sırasında daha büyük bir risk altındadır ve DNA safhalarının bu erken evrelerdeki etkinliği bir organizma için büyük önem taşımaktadir (31).

\section{Spermatozoon DNA Bütünlüğünün Değerlendirilme- si}

DNA bütünlüğünü ölçen birçok test mevcuttur. Bu testlerde, spermatozoon DNA bütünlüğünü ölçmek için kullanılan mekanizmalar farklılık gösterse de genel olarak birbirleri ile korelasyon göstermektedir. Çeşitli testler kullanılarak DNA bütünlüğünün tespiti ve karakterizasyonu ile sperması iyi dondurulabilir özellikte olan boğaların seçimi ve aynı zamanda DNA hasarıyla ilişkili olma olasıllğı yüksek çeşitli protokollerin tanımlanması kolaylaşır. Böylece, sperma depolama prosedürlerinin geliştirilmesine olanak sağlar (32). 
Tablo1 DNA hasarı tespit yöntemleri.

Table 1 Methods for the determination of sperm DNA damage.

\begin{tabular}{|c|c|c|c|c|}
\hline Teknik & Prensip & Ölçüm & Avantaj & Dezavantaj \\
\hline COMET & $\begin{array}{l}\text { DNA bütünlü- } \\
\text { gü, tek ve çift } \\
\text { zincir kırıklarının } \\
\text { kuyruklu yıldız } \\
\text { görünümü gös- } \\
\text { termesi }\end{array}$ & $\begin{array}{l}\text { Floresan } \\
\text { mikroskop }\end{array}$ & $\begin{array}{l}\text { TUNEL'e göre } \\
\text { ucuz, hassas } \\
\text { ve her bir } \\
\text { hücredeki hasar } \\
\text { oranını ölçmesi }\end{array}$ & $\begin{array}{l}\text { Özel donanım } \\
\text { gerektirmesi, } \\
\text { tecrübeye } \\
\text { dayalı olması, } \\
\text { standardize } \\
\text { edilmiş } \\
\text { yöntemlerin } \\
\text { bulunmaması }\end{array}$ \\
\hline TUNEL & $\begin{array}{l}\text { DNA fragmen- } \\
\text { tasyonu, tek ve } \\
\text { çift zincir kırık } \\
\text { ölçümü }\end{array}$ & $\begin{array}{l}\begin{array}{l}\text { Floresan } \\
\text { mikroskop }\end{array} \\
\text { Flow } \\
\text { sitometri }\end{array}$ & $\begin{array}{l}\text { Klinik açıdan } \\
\text { uygun, yüksek } \\
\text { hassasiyet ve } \\
\text { özgünlük, flow } \\
\text { sitometre ile } \\
\text { yüksek sayıda } \\
\text { inceleme şansı } \\
\text { tanıması }\end{array}$ & $\begin{array}{l}\text { Özel donanım } \\
\text { gerektirmesi, } \\
\text { pahalı olması }\end{array}$ \\
\hline SCD & $\begin{array}{l}\text { Asit solüsyon, } \\
\text { DNA denatü- } \\
\text { rasyon, } \\
\text { DNA yapısının } \\
\text { oluşturduğu } \\
\text { karakteristik halo } \\
\text { yapisı }\end{array}$ & $\begin{array}{l}\text { Floresan } \\
\text { mikroskop }\end{array}$ & $\begin{array}{l}\text { SCSA'ya göre } \\
\text { ucuz ve kolay } \\
\text { bir işlem olmas1 }\end{array}$ & $\begin{array}{l}\text { Klinik anlamı- } \\
\text { nin yeterince } \\
\text { aç1k olmaması }\end{array}$ \\
\hline SCSA & $\begin{array}{l}\text { Asit solüsyon, } \\
\text { akridin turuncu, } \\
\text { DNA denatüras- } \\
\text { yonu }\end{array}$ & $\begin{array}{l}\text { Flow } \\
\text { sitometri }\end{array}$ & $\begin{array}{l}\text { Klinik olarak } \\
\text { anlamlı yüksek } \\
\text { hassasiyete ve } \\
\text { özgünlüğe sahip } \\
\text { olması, hata ora- } \\
\text { nı düşük ölçüm } \\
\text { yapabilmesi }\end{array}$ & $\begin{array}{l}\text { Çok pahalı } \\
\text { olması ve } \\
\text { özel donanım } \\
\text { gerektirmesi }\end{array}$ \\
\hline
\end{tabular}

COMET: Tek Hücre Jel Elektroforezi, TUNEL: Sperm DNA Hasar Testi, SCD: Spermatozoon Kromatin Dağılımı, SCSA: Spermatozoon Kromatin Yapı Analizi

\section{Spermatozoon DNA Hasarının Fertilite Üzerine Etki- leri}

Erkek infertilitesinin başlıca genetik nedenleri arasında somatik ve mayotik hücrelerde yer alan kromozomal anomaliler ve gen mütasyonları yer almaktadır. Bu nedenler arasında erkek gametlerindeki DNA kusurları, histon ve DNA'daki epigenetik değisşiklikler, baz değissiklikleri ve DNA fragmentasyonu ya da DNA hasar1 yer alabilir (1). Spermatozoon DNA hasar1 etiyolojisinde iç ve dış kaynaklı çeşitli sebepler rol oynamaktadır (33). Seminal plazmadaki antioksidanların mevcudiyeti ve DNA'nın sık1 yapıda olması, spermatozoonun çekirdek DNA'sının ROS saldırılarına karşı korunduğu teorisine rağmen yine de ROS'un ve apoptosisin DNA hasarlarına neden olduğu ve bu hasarların da erkek infertilitesinde önemli bir yer tuttuğu bildirilmektedir (18). Erkek fertilitesini korumak ve aynı zamanda hayvan türlerinde genetik iyileştirmeyi sağlayabilmek için kriyoprezervasyon işleminin spermatozoon DNA yapısının olumsuz şekilde etkileneceği unutulmamalıdır (25).

Spermatozoonda DNA hasar1, hem doğal gebelik hem de in vitro fertilizasyon veya intrasitoplazmik sperm enjeksiyonunda gebelik olasıllğını azaltmakta ve erken gebelik kayıplarını artırmaktadır (33). Spermatozoon DNA bütünlüğünün korunmuş olması, başarllı bir gebelik ve genetik materyalin sonraki kuşaklara taşınması açısından büyük önem taşır. Üremeye yardımcı tekniklerin kullanımının ardından tekrarlayan başarısızlıklar erkek faktörünün önemini ortaya koymuştur. DNA bütünlüğü korunmamış bir spermatozoon ile oositin fertilize edilebilmekle birlikte, gebelik oluşması ve gebeliğin devamının gerçekleşmesi olasılığının çok düşük olduğu unutulmamalıdır. Tüm bu nedenlerle; erkek infertilitesinin tan 1 ve tedavisinde spermatozoon DNA hasarı olup olmadığının değerlendirilmesi ayrı bir önem taşımaktadır $(2,33)$.

\section{SONUÇ}

Sonuç olarak, spermatozoon DNA kalitesi, genetik materyali gelecek kuşaklara aktarmak için hayati önem taşır. Sperm DNA bütünlüğündeki değişiklikler, embriyonun ve dolayısıyla yavru anormalliklerinin gelişmesinden sorumlu olabilmektedir. Spermatozoonda oluşan DNA hasarını ölçmek amacıyla çok sayıda yöntem geliştirilmiştir. Mevcut testleri kullanarak DNA hasar değerlendirmelerinin yapılmasına karşılık, evrensel olarak kabul edilen klinik eşiklere yol açabilecek standart testlerin ve protokollerin geliştirilmesi için yeterli kaynak mevcut değildir. Bu kaynakların elde edilmesiyle spermatozoon DNA hasarlarının üreme sonuçlarındaki rolü etkin bir şekilde kavranacaktır. Son çalışmalar, spermatozoon fonksiyonunu düzenleyen moleküler mekanizmaların aydınlatılmasıyla yeni tanısal testlerin geliştirilebileceğini ortaya koymaktadır.

\section{KAYNAKLAR}

1. Jarow J, Sigman M, Kolettis PN, Lipsthultz LR, Nangia AK, Pins GS, et al. Genetic screening. The Optimal Evaluation of the Infertile Male: AUA Best Practice Statement. American Urological Association 2010; 20-3.

2. Lewis SE, Agbaje IM. Using the alkaline comet assay in prognostic tests for male infertility and assisted reproductive technology outcomes. Mutagenesis 2008; 23(3): 163-70.

3. Ferlin A, Raicu F, Gatta V, Zuccarello D, Palka G, Foresta C. Male infertility: role of genetic background. Reproductive Biomedicine Online 2007; 14(6): 734-45.

4. Hassa H. İnfertil Olgulara Klinik Yaklaşım ve IVF Laboratuar Uygulamaları. 1. Baskı. Eskişehir Osmangazi Üniversitesi Yayınları. Eskişehir 2003; s: 127-165.

5. Ward WS, Coffey DS. DNA packaging and organization in mammalian spermatozoa: comparison with somatic cells. Biology of Reproduction 1991; 44: 569-574.

6. Ward WS. Chromosome organization in mammalian sperm nuclei. Genetics of Human Male Infertility 1997; 205-221.

7. Wykes SM, Krawetz SA. The structural organization of sperm chromatin. Journal of Biology Chemistry 2003; 278: 29471-7.

8. Braun RE. Packaging paternal chromosomes with protamine. Nature Genetics 2001; 28: 102.

9. Leduc F, Maquennehan V, Nkoma GB, Boissonneault G. DNA damage response during chromatin remodeling in elongating spermatids of mice. Biology Reproduction 2008; 78: 324-332.

10. Türk G, Aksu EH, Bozkurt T. Spermatozoon DNA's hasa11. Fırat Üniversitesi Sağlık Bilimleri Dergisi 2006; 20(1): 85-95. 
11. Brugmans L, Kanaar R, Essers J. Analysis of DNA double-strand break repair pathways in mice. Mutation Research 2007; 614: 95-108.

12. Menezo Y, Dale B, Cohen M. DNA damage and repair in human oocytes and embryos. Zygote 2010; 18: 357-365.

13. Bennetts LE, de Iuliis GN, Nixon B, Kime M, Zelski K, McVicar CM, Lewis SE, Aitken RJ. Impact of estrogenic compounds on DNA integrity in human spermatozoa: Evidence for cross-linking and redox cycling activities. Mutation Research 2008; 641: 1-11.

14. Mengual L, Ballescá JL, Ascaso C, Oliva R. Marked differences in protamine content and $\mathrm{P} 1 / \mathrm{P} 2$ ratios in sperm cells from percoll fractions between patients and controls. Journal of Andrology 2003; 24: 438-447.

15. Carrell DT, Liu L. Altered protamine 2 expression is uncommon in donors of known fertility, but common among men with poor fertilizing capacity, and may reflect other abnormalities of spermiogenesis. Journal of Andrology 2001; 22: 604-610.

16. Simon L, Castillo J, Oliva R, Lewis SE. Relationships between human sperm protamines, DNA damage and assisted reproduction outcomes. Reproductive Biomedicine 2011; 23: 724-734.

17. Sakkas D, Seli E, Manicardi GC, Nijs M, Ombelet W, Bizzaro D. The presence of abnormal spermatozoa in the ejaculate: Did apoptosis fail? Human Fertility 2004; 7: 99-103.

18. Kothari S, Thompson A, Agarwal A, du Plessis SS. Free radicals: their beneficial and detrimental effects on sperm function. Indian Journal of Experimental Biology 2010; 48(5): 425-35.

19. Oehninger SC, Kruger TF. Erkek İnfertilitesi Teşhis ve Tedavi. Çeviri Editörü: Doç. Dr. Mete Kilciler, Habitat Matbaası, İstanbul 2009; s: 1-240.

20. Jiménez-Rabadán P, Ramón M, García-Álvarez O, Maroto-Morales A, del Olmo E, Pérez-Guzmán MD, Bisbal A, Fernández-Santos MR, Garde JJ, Soler AJ. Effect of semen collection method (artificial vagina vs. electroejaculation), extender and centrifugation on post-thaw sperm quality of Blanca-Celtibérica buck ejaculates. Animal Reproductive Science 2012; 132: 88-95.

21. González-Marín C, Roy R, López-Fernández C, Diez B, Carabaño MJ, Fernández JL, Kjelland ME, Moreno JF, Gosálvez J. Bacteria in bovine semen can increase sperm DNA fragmentation rates: A kinetic experimental approach. Animal Reproduction Science 201; 123: 139-148.

22. Jayaraman V, Upadhya D, Narayan PK, Adiga SK. Sperm processing by swim-up and density gradient is effective in elimination of sperm with DNA damage. Journal of Assisted Reproduction Genetics 2012; 29: 557-563.

23. De Ambrogi M, Spinaci M, Galeati G, Tamanini C. Viability and DNA fragmentation in differently sorted boar spermatozoa. Theriogenology 2006; 66: 1994-2000.

24. Lo CC, Thompson JA, Lowry VK, Varner DD. Effect of storage time and temperature on stallion sperm DNA and fertility. Theriogenology 2002; 57: 1135-1142.

25. Jackson RE, Bormann CL, Hassun PA, Rocha AM, Motta EL, Serafini PC, Smith GD. Effects of semen storage and separation techniques on sperm DNA fragmentation. Fertility and Sterility 2010; 94: 2626-2630.

26. Gosálvez J, Vázquez JM, Enciso M, Fernández JL, Gosálbez A, Bridle JR, López-Fernández, C. Sperm DNA fragmentation in rams vaccinated with miloxan. Open Veterinary Science Journal 2008; 2: 7-10.

27. Kimmins S, Sassone-Corsi P. Chromatin remodelling and epigenetic features of germ cells. Nature, 2005;434: 583-589.

28. Carrell DT, Hammoud SS. The human sperm epigenome and its potential role in embryonic development. Molecular Human Reproduction 2010; 16: 37-47.

29. Marcon L, Boissonneault G. Transient DNA strand breaks during mouse and human Spermiogenesis: New Insights in Stage Specificity and Link to Chromatin Remodeling. Biology of Reproduction 2004; 70-4,910-918.

30. Tomar DME, Chamberlin J, Allen L, Olson S, Donlon T, Barton S, Sheehy R, Waggonner D. Preferential paternal origin of de novo structural chromosome rearrangements. American Journal of Human Genetics 1984; 36: 115.

31. Jurisicova A, Latham KE, Casper RF, Casper RF, Varmuza SL. Expression and regulation of genes associated with cell death during murine preimplantation embryo development. Molecular Reproduction and Development 1998; 51: 243-253.

32. Lone SA, Shah N, Yadav P, Aurif Wagay M, Singh A, Sinha R. Sperm DNA Damage Causes, Assessment and Relationship with Fertility. Theriogenology 2017; 7(1): 13-20.

33. Krausz C. Male infertility: pathogenesis and clinical diagnosis. Best Practice Research Clinical Endocrinology Metabolism 2011; 25(2): 271-85. 